\title{
Learning from the worm: the effectiveness of protein-bound Moco to treat Moco deficiency
}

\author{
Aileen K. Sewell and Min Han \\ Department of Molecular, Cellular, and Developmental Biology, University of Colorado, Boulder, Colorado 80309, USA
}

\begin{abstract}
Molybdenum cofactor (Moco) is synthesized endogenously in humans and is essential for human development. Supplementation of Moco or its precursors has been explored as a therapy to treat Moco-deficient patients but with significant limitations. By using the nematode C. elegans as a model, Warnhoff and colleagues (pp. 212-217) describe the beneficial impact of proteinbound Moco supplementation to treat Moco deficiency. If such an effect is conserved, this advance from basic research in worms may have significant clinical implications as a novel therapy for molybdenum cofactor deficiency.
\end{abstract}

In recent years, the genetic model organism C. elegans has increasingly been used to address fundamental biological problems in the fields of cell metabolism and nutrient homeostasis, taking advantage of the conservation of most of the basic pathways and mechanisms between that in the nematode and mammals. While the conceptual advances of the studies are commonly found in the connections of metabolic events to animal development, behavior, and aging, some research results have more direct medical relevance. The study on molybdenum cofactor deficiency in this issue of Genes \& Development Warnhoff et al. (2021) presents an excellent example of using C. elegans as a unique and effective system to study the problem of nutrient deficiency.

Molybdenum $(\mathrm{Mo})$ is a transition metal that has long been known as an essential micronutrient in animals and plants (Leimkühler et al. 2011). Mo has a cofactor (Moco) and this cofactor-bound form is the catalytically active form that is used by the majority of Mo-dependent enzymes across phyla (Schwarz 2005; Mendel 2013). Moco deficiency (MoCD) is a rare genetic disorder caused by loss of Moco biosynthesis, a conserved multistep process, and results in the subsequent loss of all Mo-dependent enzyme activities; patients suffer from severe neurological damage and die prematurely (Fig. 1; Mendel

[Keywords: molybdenum cofactor; sulfite oxidase; C. elegans; E. coli] Corresponding author: mhan@colorado.edu

Article is online at http://www.genesdev.org/cgi/doi/10.1101/gad.348176. 120.
2013). While it is clear that the patients need additional Moco, the deficiency cannot be directly treated with Moco supplementation due to the instability of the Moco complex, lasting only a few minutes in neutral, aqueous environments when not bound to a protein (Schwarz 2005). Free Moco is readily oxidized and is therefore expected to be bound to protein, and thereby stabilized, immediately after synthesis.

Recent efforts using Moco precursor supplementation or gene therapy have yielded promising results for MoCD patients. Most human MoCD patients have a defect in the first step of Moco biosynthesis caused by mutations in the MOCS1 gene, referred to as MoCD type A. Researchers supplemented MoCD type A mutants with the MOCS1 product cPMP (isolated from E. coli), a stable Moco precursor, and observed significant improvements in both mouse models and human patient studies (Schwarz et al. 2004; Veldman et al. 2010; Schwahn et al. 2015). Gene therapy has also been shown to be effective to rescue Moco biosynthesis in mouse models for both type A and type B MoCD (Kügler et al. 2007; Reiss 2019). If a stable, downstream Moco supplement could be identified, it would be an ideal alternative treatment for all types of MoCD. The work by Warnhoff et al. (2021) presents a promising treatment for a MoCD deficiency model in C. elegans.

A previous study from the same laboratory demonstrated that C. elegans can use exogenous, dietary Moco from $E$. coli in addition to synthesizing endogenous Moco (Warnhoff and Ruvkun 2019), which provided the opportunity to search for a particular form of exogenous Moco that is effectively used by worms. They found that protein-bound Moco, recombinantly expressed and isolated from E. coli, red bread mold Neurospora crassa, or green algae Volvox carteri, or purified from cow's milk, was sufficient to support the growth of moc-1(-)/Geph-E mutant worms grown on Moco-deficient E. coli. They showed that the benefit of protein-bound Moco to worms is likely executed through

(C) 2021 Sewell and Han This article is distributed exclusively by Cold Spring Harbor Laboratory Press for the first six months after the full-issue publication date (see http://genesdev.cshlp.org/site/misc/terms.xhtml). After six months, it is available under a Creative Commons License (Attribution-NonCommercial 4.0 International), as described at http://creativecommons.org/licenses/by-nc/4.0/. 


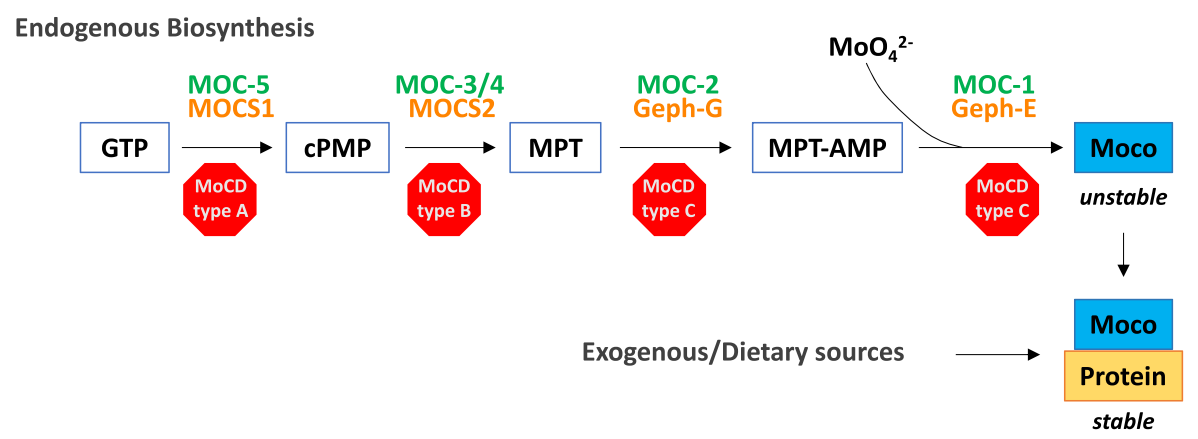

Figure 1. Diagram of Moco biosynthesis and stabilization with protein binding. The Moco biosynthesis pathway is conserved in eukaryotes, including C. elegans and humans. Loss of Moco biosynthetic enzymes results in the indicated types of Moco deficiency (MoCD). Free, unbound Moco is unstable but is stabilized when bound to proteins (e.g. sulfite oxidase). Warnhoff et al. (2021) showed that dietary supplementation with protein-bound Moco was an effective treatment for Moco deficiency in C. elegans. (MOCS1/MOCS2) Molybdenum cofactor synthesis enzymes, (Geph-G) gephyrin G-domain, (Geph-E) gephyrin E-domain (human; orange text), (MOC-1,2,3,4,5) molybdenum cofactor biosynthesis enzymes (C. elegans; green text), (GTP) guanosine triphosphate, (cPMP) cyclic pyranopterin monophosphate, (MPT) molybdopterin, (MPT-AMP) adenylated molybdopterin, (Moco) molybdenum cofactor.

an E. coli-independent mechanism that also did not rely on the endogenous Moco biosynthesis pathway in worms. The investigators further showed that the supplemented protein-bound Moco was also sufficient to rescue the defects caused by a partial loss-of-function mutation in the suox-1 gene, encoding sulfite oxidase. Sulfite oxidase is a conserved Mo-containing enzyme that is essential for both C. elegans and human development (Leimkühler et al. 2011; Warnhoff and Ruvkun 2019).

This work demonstrated that protein-bound Moco is both stable and bioavailable to C. elegans and provides a therapeutically relevant demonstration of previous observations that Moco from plant, animal, or bacterial sources can be used interchangeably and that Moco is stabilized when bound to protein (Schwarz 2005). Just as E. coli-derived cPMP was successfully used by both mice and humans in supplementation tests (Schwarz et al. 2004; Veldman et al. 2010; Schwahn et al. 2015), Warnhoff et al. (2021) demonstrated that C. elegans can use protein-bound Moco from a spectrum of exogenous origins. These findings raise a delightful possibility that proteinbound Moco from diverse sources may serve as an effective supplement for all types of MoCD patients.

More mechanistic questions remain to be addressed in future studies. It is still not understood how Moco or protein-bound Moco is transported into intestinal cells and what becomes of it in the cellular environment. Does the complex remain intact or is it broken down for utilization? Is it transported to other tissues, and by what mechanism? The investigators' previous work (Warnhoff and Ruvkun 2019) showed that MOC-1 and SUOX-1 expression in the worm hypodermis was sufficient to rescue the moc-1(-) mutant, suggesting that the hypodermis (analogous to the epidermis) is the tissue of action for Moco/SUOX-1 in C. elegans. Since dietary protein-bound Moco also rescues the moc-1(-) mutant, it may be necessary for that complex to be transported from the intestinal lumen to the hypodermis by a yet unknown mechanism. Alternatively, it is also possible that the protein-bound
Moco complex is metabolized after entering the intestinal cell for utilization by the worm. Further efforts in multicellular models and human patients will reveal the benefit and impact of this finding in C. elegans.

\section{Acknowledgments}

Work in the Han laboratory is currently supported by National Institutes of Health grants R35GM139631, R01AR074503, and R01GM047869.

\section{References}

Kügler S, Hahnewald R, Garrido M, Reiss J. 2007. Long-term rescue of a lethal inherited disease by adeno-associated virus-mediated gene transfer in a mouse model of molybdenumcofactor deficiency. Am I Hum Genet 80: 291-297. doi:10 $.1086 / 511281$

Leimkühler S, Wuebbens MM, Rajagopalan KV. 2011. The history of the discovery of the molybdenum cofactor and novel aspects of its biosynthesis in bacteria. Coord Chem Rev 255: 1129-1144. doi:10.1016/j.ccr.2010.12.003

Mendel RR. 2013. The molybdenum cofactor. J Bio Chem 288: 13165-13172. doi:10.1074/jbc.R113.455311

Reiss J. 2019. Molybdenum cofactor deficiency type B knock-in mouse models carrying patient-identical mutations and their rescue by singular AAV injections. Hum Genet 138: 355-361. doi:10.1007/s00439-019-01992-z

Schwahn BC, Van Spronsen FJ, Belaidi AA, Bowhay S, Christodoulou J, Derks TG, Hennermann JB, Jameson E, König K, McGregor TL, et al. 2015. Efficacy and safety of cyclic pyranopterin monophosphate substitution in severe molybdenum cofactor deficiency type A: a prospective cohort study. Lancet 386: 1955-1963. doi:10.1016/S0140-6736/15|00124-5

Schwarz G. 2005. Molybdenum cofactor biosynthesis and deficiency. Cell Mol Life Sci 62: 2792-2810. doi:10.1007/s00018005-5269-y

Schwarz G, Santamaria-Araujo JA, Wolf S, Lee HJ, Adham IM, Gröne HJ, Schwegler H, Sass JO, Otte T, Hänzelmann P, et al. 2004. Rescue of lethal molybdenum cofactor deficiency 
by a biosynthetic precursor from Escherichia coli. Hum Mol Genet 13: 1249-1255. doi:10.1093/hmg/ddh136

Veldman A, Santamaria-Araujo JA, Sollazzo S, Pitt J, Gianello R, Yaplito-Lee J, Wong F, Ramsden CA, Reiss J, Cook I, et al. 2010. Successful treatment of molybdenum cofactor deficiency type A with cPMP. Pediatrics 125: e1249-e1254. doi:10.1542/peds.2009-2192
Warnhoff K, Ruvkun G. 2019. Molybdenum cofactor transfer from bacteria to nematode mediates sulfite detoxification. Nat Chem Biol 15: 480-488. doi:10.1038/s41589-019-0249-y

Warnhoff K, Hercher TW, Mendel RR, Ruvkun G. 2021. Proteinbound molybdenum cofactor is bioavailable and rescues molybdenum cofactor-deficient C. elegans. Gen Dev (this issue). doi:10.1101/gad.345579.120 


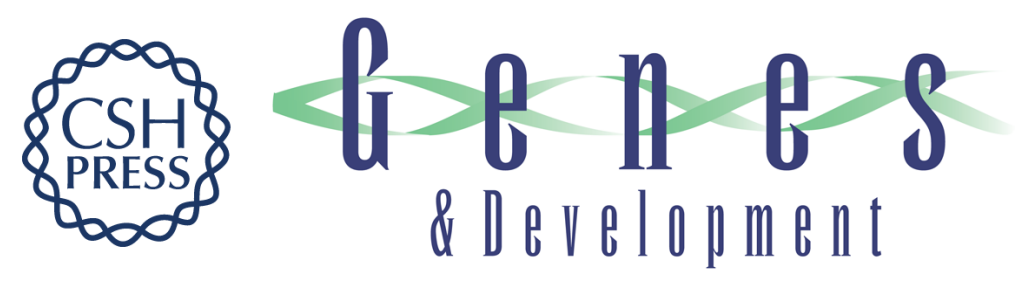

\title{
Learning from the worm: the effectiveness of protein-bound Moco to treat Moco deficiency
}

\author{
Aileen K. Sewell and Min Han
}

Genes Dev. 2021, 35:

Access the most recent version at doi:10.1101/gad.348176.120
Related Content Protein-bound molybdenum cofactor is bioavailable and rescues molybdenum cofactor-deficient C. elegans
Kurt Warnhoff, Thomas W. Hercher, Ralf R. Mendel, et al.
Genes Dev. February , 2021 35: 212-217
References This article cites 10 articles, 2 of which can be accessed free at:
http://genesdev.cshlp.org/content/35/3-4/177.full.html\#ref-list-1
Articles cited in:
http://genesdev.cshlp.org/content/35/3-4/177.full.html\#related-urls
Creative This article is distributed exclusively by Cold Spring Harbor Laboratory Press for the first
Commons
License
six months after the full-issue publication date (see
http://genesdev.cshlp.org/site/misc/terms.xhtml). After six months, it is available under a
Creative Commons License (Attribution-NonCommercial 4.0 International), as described at http://creativecommons.org/licenses/by-nc/4.0/.
Email Alerting Receive free email alerts when new articles cite this article - sign up in the box at the top
Service right corner of the article or click here.

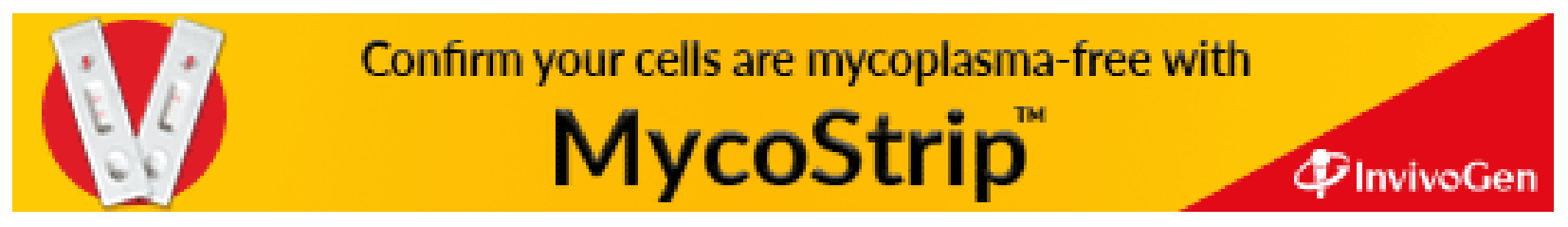

